\title{
THE SPECIFIC HEAT OF SALINE IGE
}

\author{
By Bharat Dixit and E. R. Pounder \\ (Ice Research Project, McGill University, P.O. Box 6o7o, Station A, Montreal, Canada)
}

\begin{abstract}
A calorimetric experiment was performed to determine empirically the dependence of the specific heat of ice with salinity $\mathrm{O}-10 \%$ over the temperature range from $-23^{\circ} \mathrm{C}$ to the melting point. The experimental results agree with the theoretical model determined by Schwerdtfeger (1963) for calculating the specific heat except within several degrees of the melting point and for very pure ice.

RÉsumé. La chaleur spécifique de la glace saline. On a fait une expérience calorimétrique pour déterminer les variations de la chaleur spécifique de la glace saline en fonction de la température et de la salinité. La température varie de $-23^{\circ} \mathrm{C}$ jusqu'à la température de fusion de la glace salée. La salinité des echantillons varie de $0 \%$ jusqu'à $10 \%$ par accroissements de $2 \%$. Les résultats expérimentaux sont d'accord avec ceux déterminés d'après un modèle théorique de Schwerdtfeger ( $\mathrm{r}_{9} 6_{3}$ ) sauf près de la température de fusion et pour les echantillons les plus purs.

Zusammenfassung. Die spezifische Warme salzhaltigen Eises. Auf kalorimetrischem Wege wurden empirisch die Änderungen der spezifischen Wärme salzhaltigen Eises in Abhängigkeit von Temperatur und Salzgehalt bestimmt. Der untersuchte Temperaturbereich erstreckte sich von $-23^{\circ} \mathrm{C}$ bis zum Schmelzpunkt des salzigen Eises. Der Salzgehalt dieser Proben lag zwischen o und $10 \%$. Die Ergebnisse stimmen mit dem theoretischen Modell von Schwerdtfeger ( 1963 ) zur Berechnung der spezifischen Wärme nicht aber innerhalb ein paar Grade des Schemlzpunktes oder im Falle sehr reines Eises überein.
\end{abstract}

\section{Introduction}

Determination of the specific heat of saline ice is of importance in the calculation of diffusivity $K$ of ice. This in turn will lead to better solutions of the heat diffusion equation

$$
\frac{\partial \theta}{\partial t}=K \frac{\partial^{2} \theta}{\partial x^{2}}=\frac{k}{C \rho} \frac{\partial^{2} \theta}{\partial x^{2}},
$$

where $\theta$ is temperature, $K$ the diffusivity, $k$ the thermal conductivity, $\rho$ the density, $C$ the specific heat, and $x$ and $t$ the space and time variables.

\section{THEORY}

Schwedtfeger ( 1963 ) carried out a theoretical study on the thermal conductivity, specific heat and latent heat of sea ice. Most experimental information on these properties agrees reasonably well with his calculations but this information has been obtained somewhat indirectly (e.g. through calculation of diffusivity from heat-flow measurements) and lacks precision. The experiment described here gives data from experimental measurements of the specific heat, and a comparison with Schwerdtfeger's theoretical model.

The temperature range for which this model is valid is from $-23^{\circ} \mathrm{C}$ to the freezing point of sea ice. Schwerdtfeger and Pounder ( 1962 ) divide this range into two parts: one going from the freezing point to $-8.2^{\circ} \mathrm{C}$ and the other from $-8.2^{\circ} \mathrm{C}$ to $-23^{\circ} \mathrm{C}$. To understand the division of the temperature range, we observe that in cooling sea-water below the freezing point, certain salts that make up the brine begin to precipitate as solid salt crystals. Sodium sulphate decahydrate $\left(\mathrm{Na}_{2} \mathrm{SO}_{4} \cdot \mathrm{IOH}_{2} \mathrm{O}\right)$ salts begin precipitating at $-8.2^{\circ} \mathrm{C}$ and go on precipitating in significant amounts until $-34^{\circ} \mathrm{C}$. At $-22.9^{\circ} \mathrm{C}$ it is the dihydrate of sodium chloride $\left(\mathrm{NaCl} .2 \mathrm{H}_{2} \mathrm{O}\right)$ that starts precipitating on further cooling.

It is expected that when salts precipitate as solids, the specific heat of the ice would show a discontinuity in the slope of the relationship between specific heat and temperature. Such a discontinuity is seen in the phase diagram of sea-water. In Figure $\mathrm{I}$ we have plotted the freezing point of brine against the mass ratio of dissolved salts to pure water, from Nelson and Thompson (1954). 


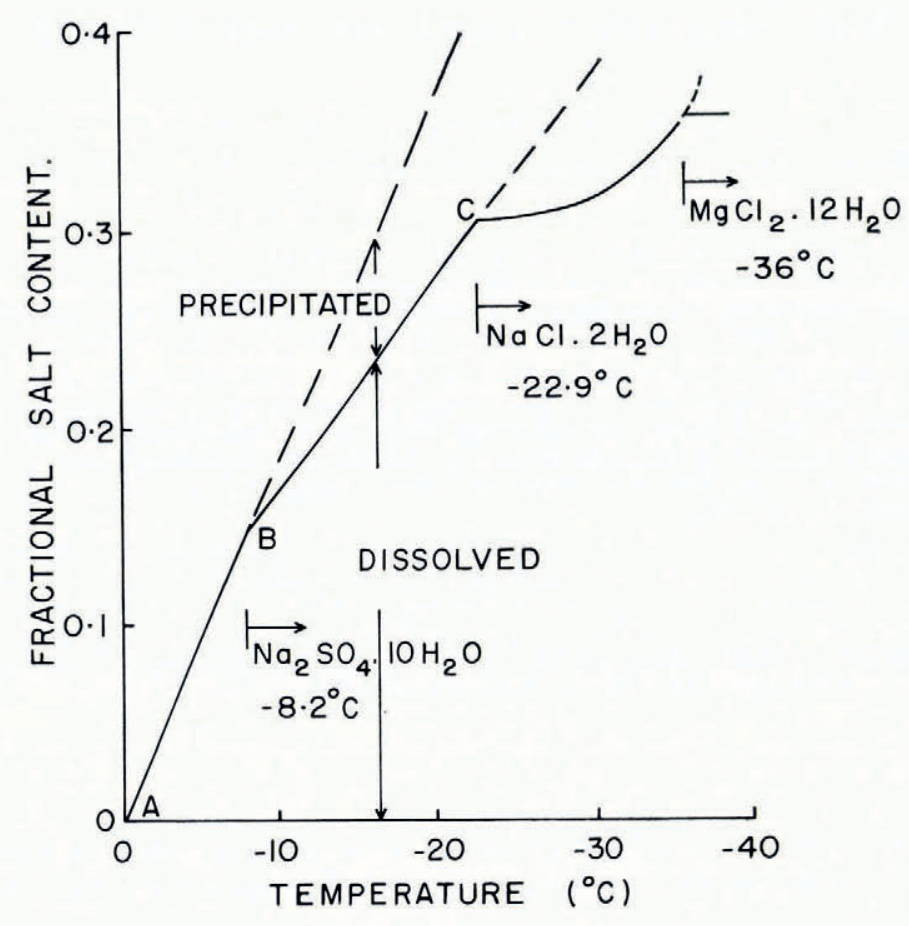

Fig. I. Phase diagram of sea-water.

If $c_{\mathrm{W}}$ and $c_{1}$ are the specific heats of pure water and pure ice respectively, then the specific heat of saline ice, for the temperature range from the freezing point to $-8.2^{\circ} \mathrm{C}$ is given by Schwerdtfeger as

$$
c_{p}=-\frac{\sigma}{\alpha \theta^{2}} L_{\mathrm{i}}+\frac{\sigma}{\alpha \theta}\left(c_{\mathrm{w}}-c_{\mathrm{i}}\right)+c_{\mathrm{i}},
$$

where $L_{\mathrm{i}}$ is the latent heat of fusion for pure ice and $\sigma$ the salinity of the ice; $\alpha=-$ o.o $84^{8}$ $\mathrm{deg}^{-\mathrm{I}}$, the slope of line $\mathrm{AB}$ in Figure $\mathrm{I}$; and $\theta$ is the temperature in degrees Celsius.

The specific heat between $-8.2^{\circ} \mathrm{C}$ and $-23^{\circ} \mathrm{C}$ is given in the theory as

$$
c_{p}=-\frac{\sigma}{\alpha \theta^{2}} L_{\mathrm{i}}+(\mathrm{I}-\sigma) c_{\mathrm{i}}+\frac{\sigma}{\alpha \theta}\left(c_{\mathrm{w}}-c_{\mathrm{i}}\right)+\sigma\left(\frac{\alpha^{\prime}}{\alpha}\right)\left(\frac{\theta+8.2 \mathrm{deg}}{\theta}\right)\left\{(\mathrm{I}+\beta) c_{\mathrm{h}}-\beta c_{\mathrm{i}}\right\}
$$

with $\alpha^{\prime}=-\mathrm{I} .0308 \times \mathrm{IO}^{-2} \mathrm{deg}^{-1}$, the slope of line $\mathrm{BC}$ in Figure $\mathrm{I}, \beta$ a number indicating the amount of water of crystallization of the salt $\mathrm{Na}_{2} \mathrm{SO}_{4}=1.27$, and $c_{\mathrm{h}}$ is the specific heat of the hydrated sodium sulphate.

We notice in Equation $(3)$ that $\left(\alpha^{\prime} \mid \alpha\right) \approx \mathrm{I}$ and $(\theta+8.2) / \theta \approx \mathrm{I}$. Thus since $\alpha$, the salinity, is of order of magnitude $\mathrm{IO}^{-3}$, we can neglect the last term and drop $-\sigma c_{\mathrm{i}}$ from the second term. With this reduction Equation (3) becomes Equation (2), so that no change in the slope of the specific heat curve should be observable.

The value of the specific heat of the saline ice as determined by Equation (2) is shown in Figure 2. Here we have used $c_{\mathrm{w}}=4.228 \times \mathrm{IO}^{3} \mathrm{~J} \mathrm{~kg}^{-1} \mathrm{deg}^{-1} ; L_{\mathrm{i}}=333.6 \times \mathrm{IO}^{3} \mathrm{~J} \mathrm{~kg}^{-1}$ and $c_{\mathrm{i}}$ the specific heat of pure ice given by Dickinson and Osborne (1915) as

$$
c_{\mathrm{i}}=\left(2.15^{8} 8+0.007795^{\theta}\right) \times \mathrm{IO}^{3} \mathrm{~J} \mathrm{~kg}^{-1} \mathrm{deg}^{-1} \text {. }
$$




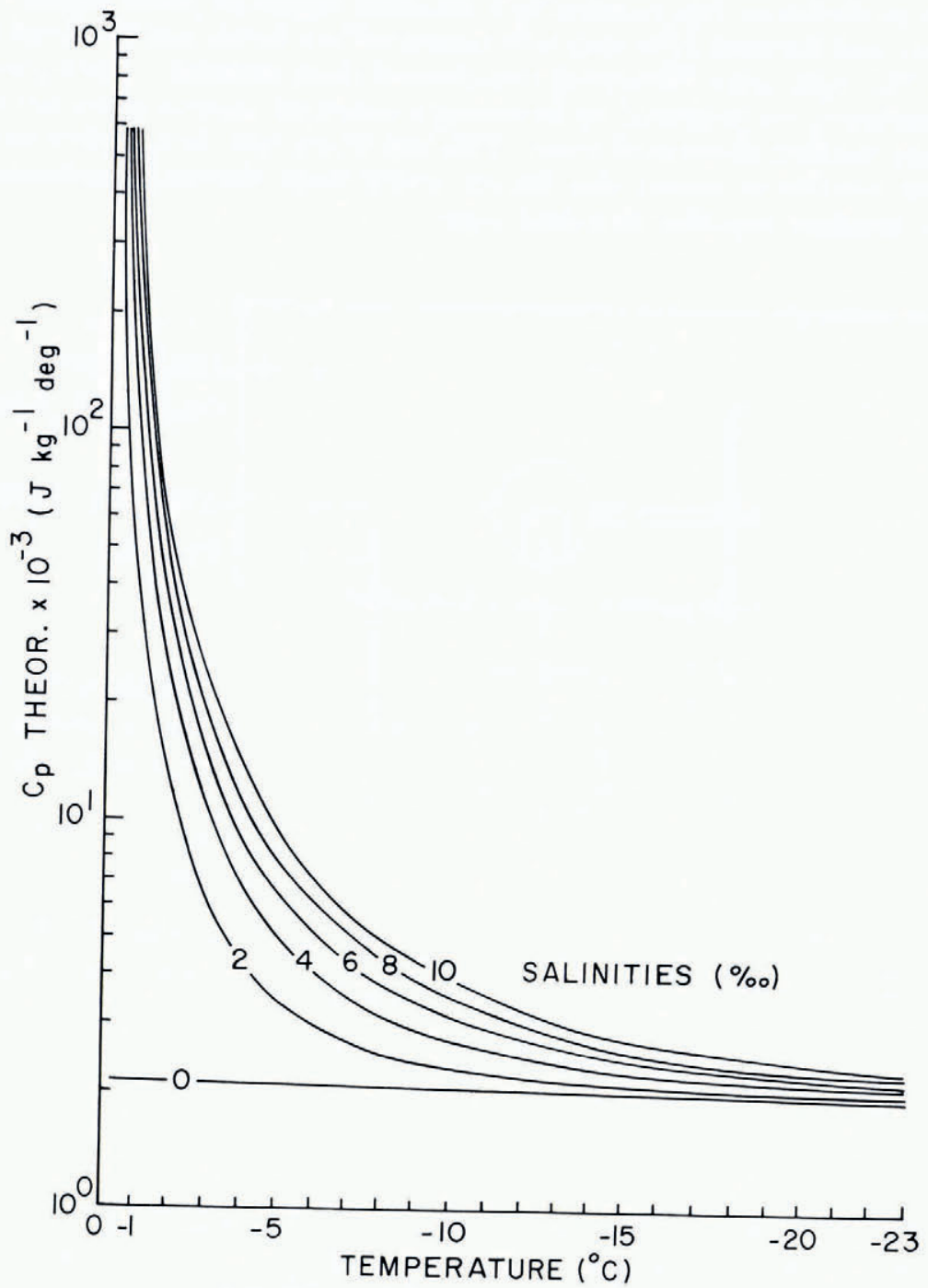

Fig. 2. Specific heat of saline ice as a function of temperature.

\section{Experiment}

\section{Equipment}

The experimental measurements on the specific heat of saline ice used the method of mixtures. The calorimeter and other equipment used in performing the experiment is shown in Figure 3. The measuring probe consists of a non-inductive heater and three iron-constantan thermocouples. It is attached to a closely fitting styrofoam cap used to seal the dewar. Two thermocouples are used to monitor temperatures inside the dewar, and a third one, arranged in a differential manner, to note temperature differences $(\Delta \theta)$ in the mixture. The calorimeter was placed in a cold box, the temperature of which could be varied by means of a $100 \mathrm{~W}$ light bulb. The temperature of the cold box was monitored using a fourth thermocouple. 
The power to the heater was supplied by a Heathkit regulated power supply IP-20. The voltage, current, and duration of heating were measured by a Leeds and Northrup differential potentiometer No. 7564 and a Honeywell two-channel chart recorder " Electronic 19". The ice for the experiment was prepared by dissolving a measured amount of sea salt in a known volume of singly distilled de-aerated water. This was frozen and then crushed to form small pieces of about $\mathrm{I}-2 \mathrm{~cm}^{3}$ to ensure that the ice would reach thermal equilibrium with the heat-exchange medium, heptane, in a short time.

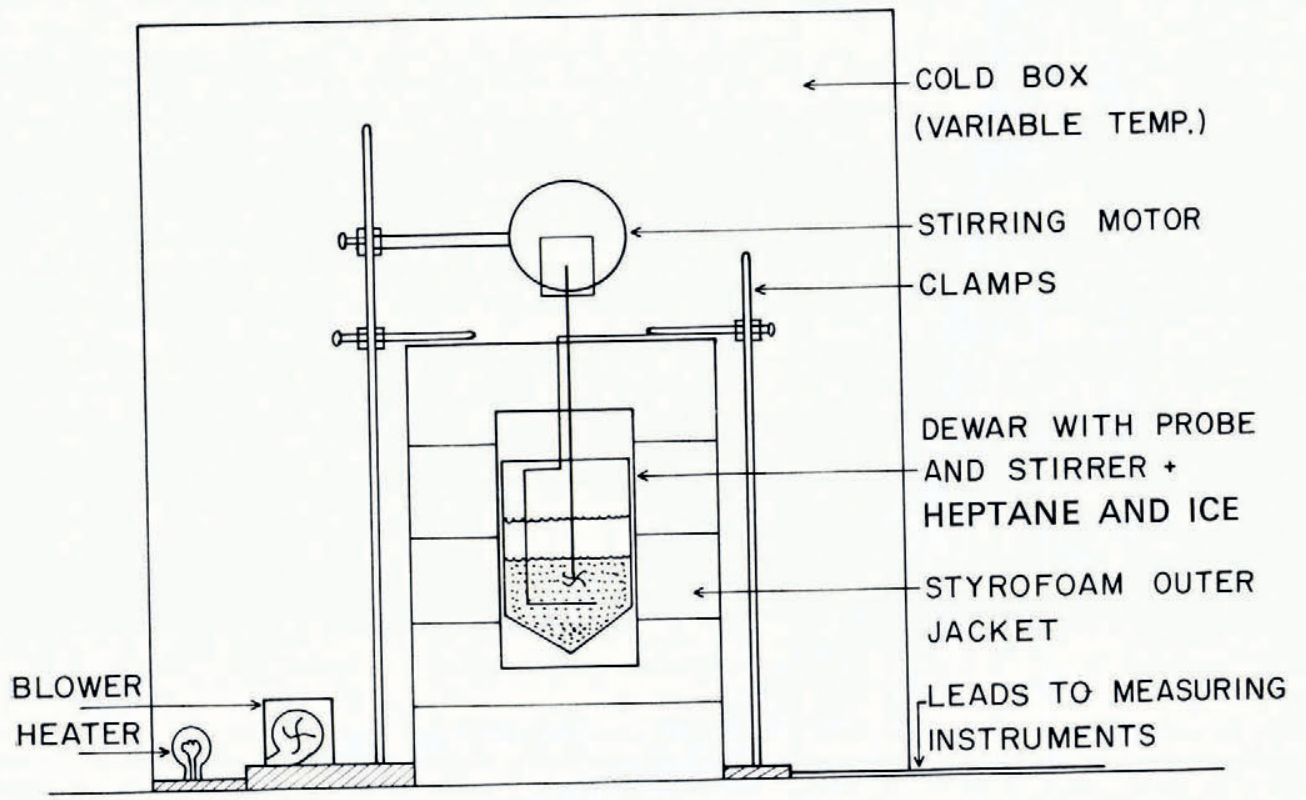

Fig. 3. Experimental apparatus in the cold room.

\section{Technique}

The experiment consisted of heating carefully measured amounts of $n$-heptane and saline ice in a dewar. The initial and final temperatures, together with the energy supplied, were recorded. The experimental procedure was as follows. Measured amounts of heptane and ice $(0.300 \mathrm{~kg}$ of each) were placed in a dewar; the dewar was then tightly closed by the probe. This mixture was stirred and the initial temperature was taken when the $\Delta \theta$ thermocouple read zero. Heat was then supplied by the heater built into the probe. The current and voltage across the heater were measured by the differential potentiometer. After a prescribed period of time (6oo s) the power was shut off and one waited for thermal equilibrium (usually I8o to $300 \mathrm{~s}$ ). When the $\Delta \theta$ thermocouple read $\pm 2 \mu \mathrm{V}$ (showing a temperature difference $<4 \times \mathrm{IO}^{-2} \mathrm{deg}$ ) the final temperature was recorded. During the run, temperatures inside the dewar were monitored for anomalies. The above procedure was repeated until the ice melted. The size of the temperature step was varied from one run to the next. The temperature steps were made as small as possible. In the beginning (i.e. near $-23^{\circ} \mathrm{C}$ ) the measured temperature intervals were about $1.5 \mathrm{deg}$ but towards the end (i.e. near the melting point) this was reduced to about $0.25 \mathrm{deg}$. The experiment was performed on ice with salinities from $0 \%$ to $10 \%$ in steps of $2 \%$. 
The temperature of the cold box was adjusted to match approximately the temperature inside the dewar in order to minimize heat losses from the latter. A cooling curve was run on the dewar, filled with heptane, for a period of several hours. The average heat loss was $0.265 \mathrm{~J} \mathrm{~s}^{-1}$ and, within the temperature ranges used, was quite insensitive to the precise temperature difference. Correction was made for this heat loss in calculating the specific heat of the ice. In a typical run the time interval between the start of heating and final temperature stabilization was $600 \mathrm{~s}$ so that the heat loss correction was about $160 \mathrm{~J}$ or about $5 \%$ of the average energy input of 3 ooo J per stage of heating.

Provision was also made of course for the heat capacity of the dewar and of the heptane. The specific heat of heptane is given by Riddick and Bunger (1970, p. 46-47) as

$$
\left(c_{p}\right)_{\text {hep }}=A+B T+C T^{2}+D T^{3}
$$

with $A=2.3627 \times \mathrm{IO}^{3} \mathrm{~J} \mathrm{~kg}^{-1} \mathrm{deg}^{-1}, B=-6.0505 \mathrm{~J} \mathrm{~kg}^{-1} \mathrm{deg}^{-2}, C=24.14 \mathrm{I} \mathrm{J} \mathrm{kg}{ }^{-1} \mathrm{deg}^{-3}$ and $D=-1.7398 \times \mathrm{IO}^{-5} \mathrm{~J} \mathrm{~kg}^{-1} \mathrm{deg}^{-4}$ for $240 \mathrm{~K}<T<370 \mathrm{~K}$.

\section{Results}

The experiment described above was performed on ice of salinities 2, 4, 6, 8 and ${ }_{10} \%$. The lowest temperature at which the specific heat was calculated was $-23.00^{\circ} \mathrm{C}$ with the warmest being $-0.30^{\circ} \mathrm{C}$. Table I shows the theoretical and experimental values of the specific heat of ice with $6 \%$ salinity. The results shown are the composite of two different

TAble I. Theoretical and EXPERimental specific heats (salinity $=6 \%$ )

\begin{tabular}{|c|c|c|c|c|}
\hline $\begin{array}{c}\text { Temperature } \\
{ }^{\circ} \mathrm{C}\end{array}$ & $\stackrel{c_{p}(\exp .) \times \mathrm{Io}^{-3}}{\mathrm{~J} \mathrm{~kg}^{-1} \mathrm{deg}^{-1}}$ & $\begin{array}{l}\text { Possible error } \\
\%\end{array}$ & $\begin{array}{c}c_{p}(\text { theor. }) \times \mathrm{IO}^{-3} \\
\mathrm{~J} \mathrm{~kg}^{-1} \mathrm{deg}^{-1}\end{array}$ & $\underset{\%}{\text { Deviation }}$ \\
\hline-21.53 & 2.233 & 2.5 & 2.204 & +1.3 \\
\hline-21.08 & 2.250 & 3.5 & 2.218 & +1.4 \\
\hline-20.66 & 2.308 & 3.1 & 2.232 & +3.4 \\
\hline$-I_{9} .8_{I}$ & 2.300 & 2.9 & 2.263 & +1.7 \\
\hline - I 9.01 & $2.3^{6} 5$ & 2.9 & 2.294 & +3.1 \\
\hline-18.75 & 2.310 & 2.7 & 2.305 & +0.2 \\
\hline-18.15 & 2.401 & 2.3 & 2.331 & +3.0 \\
\hline-17.63 & 2.421 & 2.6 & 2.356 & $\begin{array}{r}2.7 \\
+2.7\end{array}$ \\
\hline$-16.5^{2}$ & 2.476 & I.9 & 2.416 & +2.5 \\
\hline-15.71 & 2.519 & 2.0 & 2.466 & +2.1 \\
\hline-15.39 & 2.554 & I. 5 & 2.488 & $\begin{array}{r}2.7 \\
\end{array}$ \\
\hline$-14 \cdot 3^{8}$ & 2.587 & I.O & 2.565 & $\begin{array}{r}-0.8 \\
+\end{array}$ \\
\hline-14.03 & 2.612 & I. I & 2.596 & +0.6 \\
\hline-13.24 & $2.63 \mathrm{I}$ & I. I & 2.672 & +1.5 \\
\hline$-12.4^{2}$ & 2.742 & 1.3 & 2.766 & -0.9 \\
\hline-12.31 & 2.820 & 1.9 & 2.780 & +1.7 \\
\hline-11.30 & 2.985 & 1.8 & 2. 926 & +2.0 \\
\hline-10.84 & 3.027 & 1.8 & 3.006 & +0.7 \\
\hline-10.06 & 3.108 & 1. 8 & 3.166 & -1.8 \\
\hline$-9 \cdot 35$ & $3 \cdot 302$ & 2.6 & 3.345 & -1.3 \\
\hline-8.40 & 3.622 & 1.8 & 3.656 & -0.9 \\
\hline-7.54 & 3.968 & 1.8 & 4.042 & -1.9 \\
\hline-6.82 & 4.216 & 1.7 & $4 \cdot 4^{81}$ & -6.8 \\
\hline$-6.6 o$ & 4.660 & 2.5 & 4.644 & +0.3 \\
\hline$-5 \cdot 72$ & $5 \cdot 312$ & 2.5 & 5.490 & -3.2 \\
\hline$-5 \cdot 46$ & 5.549 & I. 7 & 5.820 & -4.7 \\
\hline-4.99 & $6.35^{8}$ & 2.0 & $6.55^{2}$ & -3.0 \\
\hline-4.82 & 6.640 & 2.8 & 6.870 & -3.4 \\
\hline-4.22 & 8.606 & 3.0 & $8.3^{1} 4$ & +3.5 \\
\hline$-3 \cdot 70$ & 9.910 & 2.5 & 10.17 & -2.6 \\
\hline-3.09 & 14.26 & 2.8 & 13.64 & +4.5 \\
\hline-2.79 & 16.31 & 3.1 & 16.24 & +0.5 \\
\hline-2.10 & 27.77 & 4.2 & $26.9^{6}$ & +3.0 \\
\hline-1.86 & 35.28 & 3.8 & 33.75 & +4.5 \\
\hline$-1.4^{8}$ & 63.33 & 3.6 & $5^{1.98}$ & $\begin{array}{r}1.8 \\
+21.8\end{array}$ \\
\hline-1.07 & 11 $1.9^{2}$ & 5.1 & 97.29 & +15.0 \\
\hline
\end{tabular}


runs. For brevity, detailed results are listed for this value of salinity only as it is representative of the whole range of saline ice studied. For temperatures below $-2^{\circ} \mathrm{C}$ the agreement between theoretical and experimental values is quite satisfactory, most deviations being about the same or less than the estimated possible error in column 3 .

Although at least two runs were made at each salinity the data points for a given temperature and salinity were too few for a statistical analysis, and consequently possible errors in weighing the ice and heptane, in reading the heater input voltage and current and in temperature readings were estimated and combined to give a "maximum" possible error. Because of the small temperature differences involved possible errors in temperature readings were the dominant factor, especially at higher temperatures. The method of correcting for heat losses was described earlier and we have no check on its adequacy. From Table I the experimental values are higher than the theoretical ones in a large majority of cases. This may indicate some factor overlooked in the theoretical analysis; to us, it seems more likely to be an indication that heat losses have been underestimated.

Salinities of the ice used were determined using a Hytech Salinometer which has an accuracy of about $0.001 \%$. When the salt solution was frozen, brine rejection resulted in higher salinities at the surfaces of the block, especially the top and bottom. Only the centre part was used. After crushing it into small pieces part was used for the experimental runs and part melted for salinity measurement.

Table II gives a summary of the deviations between observed and predicted values of specific heat for all salinities studied. Since the results are quite erratic at higher temperatures, the range has been arbitrarily divided as shown. Both the mean absolute value of the deviation and its mean value are listed. The large deviations in the high temperature range are not, to us, surprising although we have no proven explanation. The effect of inaccuracies in temperature measurement is more important, and the sampling technique for determining salinity could have resulted in small differences between that measured and the actual salinity of the sample tested. Figure 2 shows the large effect of salinity on specific heat at these temperatures.

Table II. Percentage deviation of experimental and theoretical values of specific heat

\begin{tabular}{|c|c|c|c|c|c|c|}
\hline \multirow{3}{*}{$\begin{array}{c}\text { Salinity } \\
\%\end{array}$} & \multicolumn{6}{|c|}{ Temperature range } \\
\hline & \multicolumn{3}{|c|}{$-23.00^{\circ} \mathrm{C}$ to $-2.00^{\circ} \mathrm{C}$} & \multicolumn{3}{|c|}{$-\mathrm{r} .99^{\circ} \mathrm{C}$ to $0.00^{\circ} \mathrm{C}$} \\
\hline & $\begin{array}{c}\text { average } \\
\mid \text { deviation } \mid\end{array}$ & $\begin{array}{c}\text { average } \\
\text { deviation }\end{array}$ & $\begin{array}{c}\text { maximum } \\
\text { deviation }\end{array}$ & $\begin{array}{c}\text { average } \\
\text { |deviation| }\end{array}$ & $\begin{array}{l}\text { average } \\
\text { deviation }\end{array}$ & $\underset{\text { deviation }}{\operatorname{maximum}}$ \\
\hline 2 & 2.1 & +0.82 & +9.9 & I 3.5 & -2.47 & +21.1 \\
\hline 4 & 2.3 & $+0.5^{2}$ & -7.9 & $9 \cdot 7$ & +2.02 & -15.4 \\
\hline 6 & 2.2 & +0.30 & -6.8 & 13.8 & +13.80 & +21.8 \\
\hline 8 & 2.5 & -0.86 & -9.6 & $7 \cdot 5$ & $+4.5^{1}$ & +16.7 \\
\hline 10 & I.9 & +0.77 & -6.7 & 8.6 & +6.21 & +11.7 \\
\hline
\end{tabular}

A check was attempted on ice frozen from singly distilled, de-aerated water but without much quantitative success. At temperatures below $-4^{\circ} \mathrm{C}$ there was qualitative agreement with the known, slow variation of $c_{p}$ with temperature but with a considerable scatter of results (deviations as high as $10 \%$ ). Above $-4^{\circ} \mathrm{C}$ the curve of specific heat against temperature (not shown) was similar in form to those in Figure 2 for saline ice although the maximum value of $c_{p}$ measured $\left(1.2 \times 10^{4} \mathrm{~J} \mathrm{~kg}^{-1} \mathrm{deg}^{-1}\right.$ at $\left.-0.30^{\circ} \mathrm{C}\right)$ was naturally much lower. In their classic experiment, Dickinson and Osborne (I9I5) used repeatedly distilled water but still found spuriously high values of the specific heat near the melting point, values which were not reproducible from sample to sample and which they attributed to trace impurities left in the water even after several distillations. 


\section{Acknowledgements}

This study was supported by the Department of Energy, Mines and Resources under Contract PCSP 70-53. The computations were done on the McGill University IBM $360 / 75$
computer.

MS. received I4 August 1974 and in revised form 9 June 1975

\section{REFERENCES}

Dickinson, H. C., and Osborne, N. S. 1915. Specific heat and latent heat of fusion of ice. Scientific Paper No. S248. Bulletin of the Bureau of Standards (Washington, D.C.), Vol. 12, No. I, p. 49-81. Nelson, K. H., and Thompson, T. G. 1954. Deposition of salts from sea water by frigid concentration. Fournal of
Marine Research, Vol. 13, No. 2, p. 166-82.

Riddick, J. A., and Bunger, W. B. 1970. Techniques of chemistry. Vol. 2. Organic solvents, physical properties and methods of purification. Third edition. New York, John Wiley, Interscience.

Schwerdtfeger, P. 1963 . The thermal properties of sea ice. Fournal of Glaciology, Vol. 4, No. 36, p. $789-807$. Schwerdtfeger, P., and Pounder, E. R. 1962. The thermal properties of sea ice and energy exchanges between
ice and atmosphere. McGill University, Montreal. Ice Research Project. Report S-1 o. 